\title{
Kwota wolna od opodatkowania a sprawiedliwość podatkowa
}

\author{
Jacek Wasilewski \\ Katedra Antropologii Mediów, Wydział Dziennikarstwa, Informacji i Bibliologii, \\ Uniwersytet Warszawski
}

\begin{abstract}
Aleksander Werner
Katedra Prawa Administracyjnego i Finansowego Przedsiębiorstw, Kolegium Nauk o Przedsiębiorstwie, Szkoła Główna Handlowa w Warszawie

Katarzyna Kimla

Katedra Prawa Administracyjnego i Finansowego Przedsiębiorstw, Kolegium Nauk o Przedsiębiorstwie, Szkoła Główna Handlowa w Warszawie
\end{abstract}

\section{Agata Kostrzewa}

Wydział Dziennikarstwa, Informacji i Bibliologii, Uniwersytet Warszawski

Celem artykułu jest analiza instytucji kwoty wolnej od podatku, stanowiącej minimum podatkowe, poniżej którego wartość osiągniętego dochodu nie podlega opodatkowaniu, przez pryzmat zasad sprawiedliwości podatkowej oraz sprawiedliwości w ujęciu polityki społecznej. W artykule dokonano zdefiniowania kwoty wolnej od opodatkowania na podstawie przeglądu literatury oraz ustalenia jej miejsca w katalogu funkcji pełnionych przez prawo podatkowe. Wyniki badania opinii pozwoliły natomiast na dokonanie analizy, w jaki sposób respondenci deklarują ocenę kwoty wolnej od podatku. Wnioski z przeprowadzonych analiz mogą stanowić podstawę dalszych badań nad sprawiedliwością opodatkowania.

Słowa kluczowe: wynagradzanie, opodatkowanie, kwota wolna od opodatkowania, minimum podatkowe, minimum egzystencji, podatek dochodowy 


\section{Minimum podatkowe - istota $\mathrm{i}$ rola $\mathrm{w}$ systemie podatkowym}

Idea sprawiedliwości podatkowej znajduje wyraz w rozłożeniu ciężarów podatkowych i dostosowaniu ich do zindywidualizowanych możliwości podatnika (Litwińczuk, 1989). Postulatom tym odpowiadało pojawienie się koncepcji personalizacji podatku i wykształcenie się takich konstrukcji podatkowych, jak minimum egzystencji, ulgi rodzinne, progresja podatkowa czy dyskryminacja dochodów w zależności od źródła dochodów, nawiązujących do funkcji redystrybucyjnej opodatkowania (Kaplow, 2006). Minimum egzystencji i ulgi rodzinne pojawiły się $\mathrm{w}$ pierwszych systemach podatków dochodowych jeszcze przed wykształceniem się innych konstrukcji odwołujących się do sytuacji materialnej podatnika ${ }^{1}$. Konstrukcje te historycznie służyły wyłączeniu spod opodatkowania określonej kwoty dochodu, która była określana jako niezbędna do utrzymania przy życiu i zdolności do pracy podatnika wraz z jego rodziną (Litwińczuk, 1989). Źródeł minimum podatkowego upatruje się w reformie D. Lloyda Georga z lat 1909/1910, obejmującej tzw. super-tax, który obciążał całość dochodu przekraczającą minimum osiągnięte przez podatnika ze wszystkich źródeł podlegających opodatkowaniu (Douglas, 2011). W ten sposób podatek dochodowy nabrał cech progresywności, zgodnie z którą super-tax był płacony jedynie od części dochodu przekraczającego minimum (Rybarski, 1935; Adam, 1962; Douglas, 2011). Przytoczone w niniejszym artykule rozwiązania pokazują, że system podatkowy przynależy nie tylko do polityki fiskalnej i gospodarczej państwa, lecz także staje się elementem prowadzenia polityki społecznej.

Minimum podatkowe odpowiada kwocie osiągniętego w danym roku dochodu, poniżej której podatnik nie uiszcza podatku (Etel, 2010). Minimum podatkowe w tym znaczeniu jest ściśle powiązane z podstawą opodatkowania, która jest elementem konstrukcyjnym każdego podatku (oprócz podmiotu, przedmiotu, stawki, ulg i zwolnień). Minimum podatkowe jest także określane w literaturze jako „kwota wynagrodzenia wolnego od podatku od wynagrodzeń” - stanowi więc dolną granicę opodatkowania. W tym kontekście, co do zasady, wysokość wynagrodzenia poniżej wartości minimum podatkowego nie podlega opodatkowaniu, z chwilą jednak, gdy wynagrodzenie jest wyższe niż ustalone przez ustawodawcę minimum podatkowe, może ono stanowić $\mathrm{w}$ całości podstawę opodatkowania (Jandy-Jendrośka, 1973).

1 Minimum egzystencji i ulgi rodzinne stosowano w angielskim podatku dochodowym już od 1803 r., w pruskim od 1891 r., austriackim od 1896 r. i niemieckim od 1920 r. (Litwińczuk, 1989). 
Kwota minimum podatkowego (określana także jako kwota wolna od opodatkowania) przybiera różne formy w zależności od przyjętego rozwiązania prawnego (Etel, 2010):

- kwota ta może zostać podana w sposób bezpośredni jako odwołanie do limitu, poniżej którego podatek nie jest naliczany (np. w podatku od spadków i darowizn),

- w przypadku progresywnego systemu opodatkowania, kwota wolna może odpowiadać stawce $0 \%$, która jest stosowana w pierwszym przedziale podstawy opodatkowania,

bądź też jest to kwota, która pomniejsza podstawę opodatkowania poprzez jej potrącenie od wysokości podatku należnego (Litwińczuk, 2012).

Z punktu widzenia oceny minimum podatkowego przez pryzmat sprawiedliwości wynagradzania jest istotne, czy minimum podatkowe jest traktowane przez ustawodawcę jako dolna granica opodatkowania, czy też jako kwota potrącalna dla każdego podatnika. W drugim przypadku, gdy minimum podatkowe jest ukształtowane jako kwota potrącalna od postawy opodatkowania (często także zróżnicowana w zależności od sytuacji rodzinnej podatnika), jest instrumentem łagodzącym progresywność opodatkowania, zwłaszcza w przypadku niskich dochodów (Jandy-Jendrośka, 1973). Taka też konstrukcja znajduje odzwierciedlenie w polskim systemie podatkowym (Obwieszczenie ..., 2017, art. 27 ust. 1a).

Można także spotkać pogląd, zgodnie z którym minimum podatkowe jest kwalifikowane jako rodzaj ulgi podatkowej, przy czym ulga podatkowa obejmuje każdą sytuację, która powoduje obniżkę podatku (ulga podatkowa sensu largo). W tak przyjętym toku rozumowania można powiedzieć, że każde rozwiązanie, które polepsza sytuację finansową podatnika (w tym wprowadzenie w systemie podatkowym kwoty wolnej od opodatkowania) będzie traktowane jako ulga podatkowa (Nykiel, 2002).

Kwota wolna od opodatkowania pełni dwie główne funkcje w systemie prawa podatkowego:

1) stanowi socjalny wymiar opodatkowania,

2) odpowiada na zasadę taniości systemu podatkowego.

Społeczny aspekt minimum podatkowego odwołuje się do pozostawienia podatnikom wolnego od podatków pewnego poziomu dochodów, który Państwo uznaje za poziom, jaki jest niezbędny do zaspokojenia minimalnych potrzeb egzystencjalnych obywateli i w tym kontekście nie powinien podlegać opodatkowaniu (Sosnowski, 2015). W kontekście sprawiedliwości opodatkowania wskazuje się, że: - nikt nie powinien płacić wyższych podatków „aniżeli jest w stanie płacić” (A. Smith, 1954),

- $\quad$ z opodatkowania powinny zostać wyłączone dochody na poziomie, jaki odzwierciedla „niezbędne dla życia minimum” (Gomułowicz, 2001). 
W tym kontekście społeczny aspekt minimum podatkowego nawiązuje do zdolności płatniczej jako do maksymy sprawiedliwości podatkowej (Fedorowicz, 1998).

Zasada taniości opodatkowania (Smith, 1954) odwołuje się do nieangażowania aparatu skarbowego w postępowania $\mathrm{w}$ zakresie obliczania kwot podatków od niewielkich podstaw opodatkowania, co wpływa na redukcję kosztów poboru podatku. W tym aspekcie wprowadzenie kwoty wolnej od opodatkowania ogranicza sytuację, w której wysokość kosztów poboru podatku byłaby niewspółmiernie wysoka w stosunku do uzyskiwanych dochodów budżetu państwa. Ponadto, brak ustalenia minimum podatkowego mógłby doprowadzić do sytuacji - zwłaszcza w przypadku podatników osiągających dochody na granicy minimum socjalnego - w której nastąpiłby wtórny zwrot pobranych podatków w postaci innych form pomocy społecznej i świadczeń, co byłoby sprzeczne także z zasadą racjonalności i efektywności ekonomicznej finansów publicznych (Kosek-Wojnar, 2012).

Współczesne systemy podatkowe odwołują się głównie do roli socjalnej kwoty wolnej od opodatkowania. W założeniu, kwota minimum podatkowego powinna gwarantować opodatkowanym niezbędne minimum ich egzystencji i odzwierciedlać wartość koszyka dóbr i usług zapewniającego społecznie akceptowalny minimalny poziom życia. W praktyce jednak, powiązanie kwoty minimum podatkowego $\mathrm{z}$ minimum socjalnym jest trudne do zastosowania. Taka konstrukcja wymagałaby bowiem indywidualizacji opodatkowania, a określenie minimum powinno być uzależnione od sytuacji osobistej podatnika, uwzględniając m.in. nierówności w aspekcie geograficznym (Sobiech, 2003). W tym kontekście, ustalenie poziomu minimum podatkowego jest wyborem raczej arbitralnym aniżeli mechanizmem zapewniającym zabezpieczenie minimum egzystencji.

\section{Degresywność kwoty wolnej od opodatkowania a sprawiedliwość podatkowa}

Do końca 2016 r. wysokość kwoty wolnej od opodatkowania była wartością stałą i wynosiła 556,02 PLN (Ustawa ..., 1991, art. 27 ust 1a). Z dniem 1 stycznia 2017 r. weszły w życie nowe przepisy mające zastosowanie do dochodów uzyskanych od tego dnia, określające częściowe uzależnienie wysokości kwoty wolnej od podatkowania od ustalonych - wciąż arbitralnie - kwot dochodu osiąganych przez podatników. W obecnym kształcie przepisów wysokość minimum podatkowego zależy od wysokości osiągniętego dochodu, zakładając, że im wyższy całkowity dochód osiągnięty przez podatnika, tym niższa jest wartość kwoty niepodlegającej opodatkowaniu (degresywny sposób ukształtowania wysokości minimum 
podatkowego) (Topińska, 2017). Kwota zmniejszająca podatek wynosi obecnie od kwoty 1440 PLN rocznie dla podstawy obliczenia podatku nieprzekraczającej 8000 PLN (w 2018 r.), do kwoty 556,02 PLN, pomniejszonej o kwotę obliczoną według wzoru:

\section{6,02 PLN $\times($ podstawa obliczenia podatku - 85528 PLN $) \div 41472$ PLN}

dla podstawy obliczenia podatku wyższej niż 85528 PLN i nieprzekraczającej kwoty 127000 PLN rocznie (Obwieszczenie ..., 2017, art. 27 ust. 1). Tak ukształtowana konstrukcja kwoty wolnej od opodatkowania odwołuje się do zdolności płatniczej i koncepcji sprawiedliwości pionowej opodatkowania.

Zmiana sposobu określania kwoty wolnej od opodatkowania była wynikiem wyroku Trybunału Konstytucyjnego, zgodnie z którym przepis określający poziom minimum podatkowego: „w zakresie, w jakim nie przewiduje mechanizmu korygowania kwoty zmniejszającej podatek, gwarantującego co najmniej minimum egzystencji, jest niezgodny z art. 2 i art. 84 Konstytucji Rzeczypospolitej Polskiej" (Wyrok Trybunału Konstytucyjnego ..., 2015). Wyrok ten, skutkujący zmianą przepisów podatku dochodowego od osób fizycznych w zakresie mechanizmu określenia wysokości kwoty zmniejszającej podatek, został zainicjowany wnioskiem Rzecznika Praw Obywatelskich (dalej: RPO)2 . W złożonym wniosku RPO wskazywał na konieczność weryfikacji przyjętego przez ustawodawcę założenia, zgodnie z którym przekroczenie przez podatnika kwoty wolnej od opodatkowania świadczy o tym, że podatnik w granicach tak ustalonego dochodu jest w stanie zaspokoić swoje elementarne potrzeby życiowe oraz ma zdolność do ponoszenia ciężarów publicznych w postaci uiszczania podatku.

W uzasadnieniu do wniosku RPO odwołał się do określonej w art. 84 Konstytucji Rzeczpospolitej Polskiej (1997) zasady sprawiedliwości podatkowej. W uzasadnieniu wniosku wskazał, że nałożenie obowiązków podatkowych znajduje bezpośrednią podstawę w Konstytucji Rzeczpospolitej Polskiej oraz nie może prowadzić do ograniczenia praw jednostki, ale powinno się odnosić do zdolności ponoszenia ciężarów i świadczeń publicznych przez obywateli.

W ocenie RPO, ustalenie kwoty wolnej od opodatkowania na stałym poziomie nieuwzględniającym zdolności płatniczej podatnika narusza zasady wynikające z powołanych wzorców konstytucyjnych: sprawiedliwości społecznej i sprawiedliwości podatkowej. Tak ukształtowane minimum podatkowe: „ustala bowiem

2 W dniu 6 października 2014 r. Rzecznik Praw Obywatelskich złożył do Trybunału Konstytucyjnego wniosek o stwierdzenie, że art. 27 ust. 1 ustawy z dnia 26 lipca 1991 r. (Ustawa ..., 1991), w zakresie, w jakim ustala w pierwszym przedziale skali podatkowej kwotę zmniejszającą podatek w wysokości 556,02 PLN, jest sprzeczny z art. 2 i art. 84 Konstytucji Rzeczpospolitej Polskiej (1997). 
kwotę wolną od podatku w oderwaniu od przyjętych w obowiązującym prawie, a więc mających znaczenie normatywne, kryteriów ubóstwa"3.

\section{Kwota wolna od opodatkowania w narracjach polityków}

Kwota wolna od opodatkowania pojawia się także w wypowiedziach polityków. Przykładowo, w 2015 r. Twój Ruch proponował, aby wysokość kwoty wolnej od podatku zależała od wysokości minimum egzystencji, odwołując się do sprawiedliwości społecznej: „Należy uznać, iż w najwyższym stopniu niemoralna i zarazem sprzeczna z elementarnym poczuciem sprawiedliwości społecznej jest obecna sytuacja, w której państwo pobiera daniny od dochodów, które nie pozwalają na pokrycie wydatków na żywnośći opłaty za mieszkanie" (Nie będzie ..., 2015). Projekt jednak został odrzucony (Nie będzie ..., 2015).

Kwota wolna od opodatkowania powróciła do dyskursu dzięki wypowiedziom Premiera M. Morawieckiego. W jego narracji jest ona instrumentem obniżania podatków: „Obniżymy podatki poprzez to, że od 1 stycznia 2018 roku znacząco, znowu, po raz drugi, zwiększymy kwotę wolną od podatku - z 6,6 tys. zł na 8 tys. zł dla tych najuboższych osób" (Morawiecki ..., 2017).

Warto także zwrócić uwagę, że kilkakrotnie Premier przytaczał w milionach liczbę beneficjentów wprowadzenia podwyższenia kwoty wolnej od opodatkowania, co jest sposobem podkreślenia przez M. Morawieckiego zmiany statusu znacznej części społeczeństwa dzięki działaniom rządu.

Biorąc pod uwagę, że mechanizm obliczania kwoty wolnej od opodatkowania należy do dosyć skomplikowanych dla osób niebędących specjalistami, proste wytłumaczenie podawane przez polityków, odwołujące się do sprawiedliwości społecznej czy troski o los osób o najniższych dochodach, jest wykorzystywane politycznie do budowania poparcia społecznego.

We wspomnianym projekcie Twojego Ruchu autorzy propozycji wskazywali, że ówczesna kwota wolna od opodatkowania jest ponad dwukrotnie niższa od dwunastokrotności minimum egzystencji $\mathrm{w}$ jednoosobowym gospodarstwie pracowniczym. Istniejąca kwota wolna od podatku także obecnie nie ma wiele wspólnego z minimum egzystencji, funkcjonuje bowiem jako abstrakcyjny próg, poniżej którego osiągnięty dochód nie jest opodatkowany. Nie jest więc realnie rozwiązaniem, które może poprawić sytuację obywateli.

3 http://orka.sejm.gov.pl/stanowiskatk.nsf/nazwa/Stanowisko_K_21_14/\$file/Stanowisko_ K_21_14.pdf (1.07.2018). 


\section{Ocena kwoty wolnej od opodatkowania w świetle badań opinii}

Badania opinii zrealizowane przez zespół badawczy złożony przez przedstawicieli Szkoły Głównej Handlowej w Warszawie i Uniwersytetu Warszawskiego miały m.in. na celu ocenę instrumentu kwoty wolnej od opodatkowania w deklarowanych opiniach respondentów. Badania powstały w wyniku realizacji projektu badawczego nr 2016/21/B/HS4/02992 pt. Sprawiedliwość wynagradzania, finansowanego ze środków Narodowego Centrum Nauki. Badanie zostało przeprowadzone w listopadzie 2017 r. na reprezentatywnej próbie pracujących Polaków ( $N=1067)$ techniką telefoniczną CATI (Computer Assisted Telephone Interviewing) przez firmę Kantar MillwardBrown. Dobór respondenta był losowy. Na potrzeby niniejszego artykułu zostały przeanalizowane odpowiedzi w zakresie oceny kwoty wolnej od opodatkowania w kontekście deklaracji respondentów co do oceny jej zasadności (rysunek 1) oraz oceny czynników, jakie powinny wpływać na jej wysokość (rysunek 2).

Jak wynika z przeprowadzonego badania, zdecydowana większość respondentów deklaruje, że system podatkowy powinien uwzględniać kwotę wolną od opodatkowania. Brak jest istotnych rozbieżności w deklarowanych odpowiedziach uwzględniając zarówno płeć respondenta, jak i pozostałe parametry analizy. Z zaprezentowanego rozkładu rysunku 1 wynika, że relatywnie krytyczne opinie deklarują osoby ze średnim wykształceniem oraz respondenci w przedziale wiekowym 18-24 lata oraz 35-44 lata Na podstawie wykonanych korelacji nie widać jednak silnych zależności między deklarowanymi osądami kwoty wolnej od opodatkowania a danymi z metryki respondenta. W zakresie rozkładu odpowiedzi można zaobserwować, że respondenci o deklarowanym dochodzie powyżej 10000 PLN (najwyższa klasa) deklarują najbardziej krytyczny stosunek do instytucji kwoty wolnej od opodatkowania (13\% respondentów zadeklarowało „nie”, podczas gdy średnia w próbie wyniosła 5\%). Rozkład ten jest zaskakujący, ponieważ w przedziale deklarowanego dochodu w wysokości 5500-10 000 PLN odsetek negatywnych opinii jest znacznie mniejszy (4\% przy średniej z próby 5\%).

Deklaracje respondentów w zakresie czynników, jakie powinny wpływać na wysokość minimum podatkowego, przedstawiono na rysunku 2.

W ocenie respondentów, ustalenie czynników, jakie powinny wpływać na wysokość kwoty wolnej od opodatkowania nie jest już tak jednolite. Większość respondentów deklaruje, że kwota wolna od opodatkowania powinna zależeć od wysokości wynagrodzenia (co potwierdzałoby społeczną akceptację dokonanych zmian legislacyjnych), odzwierciedlać minimalny dochód pozwalający przeżyć oraz zależeć od sytuacji rodzinnej podatnika (co może stanowić podstawę dalszych 
Rysunek 1. Deklaracja oceny respondentów zasadności istnienia kwoty wolnej od opodatkowania
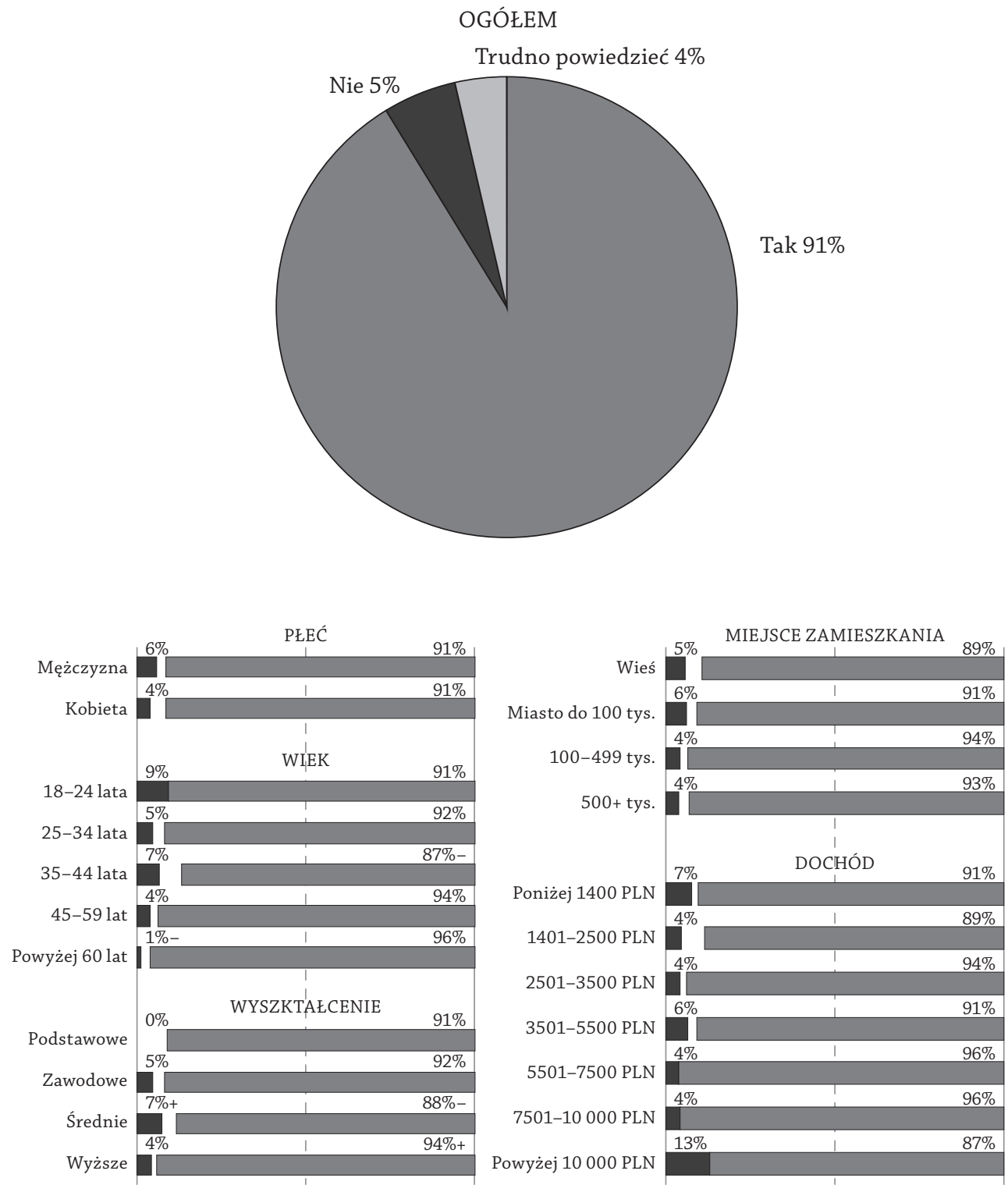

$N=1003$

Uwaga: +\- różnice statystycznie w stosunku do wszystkich respondentów istotne na poziomie 95\%.

Źródło: badanie Kantar MillwardBrown. 
Rysunek 2. Deklaracja oceny respondentów czynników, jakie powinny mieć wpływ na wysokość kwoty wolnej od opodatkowania

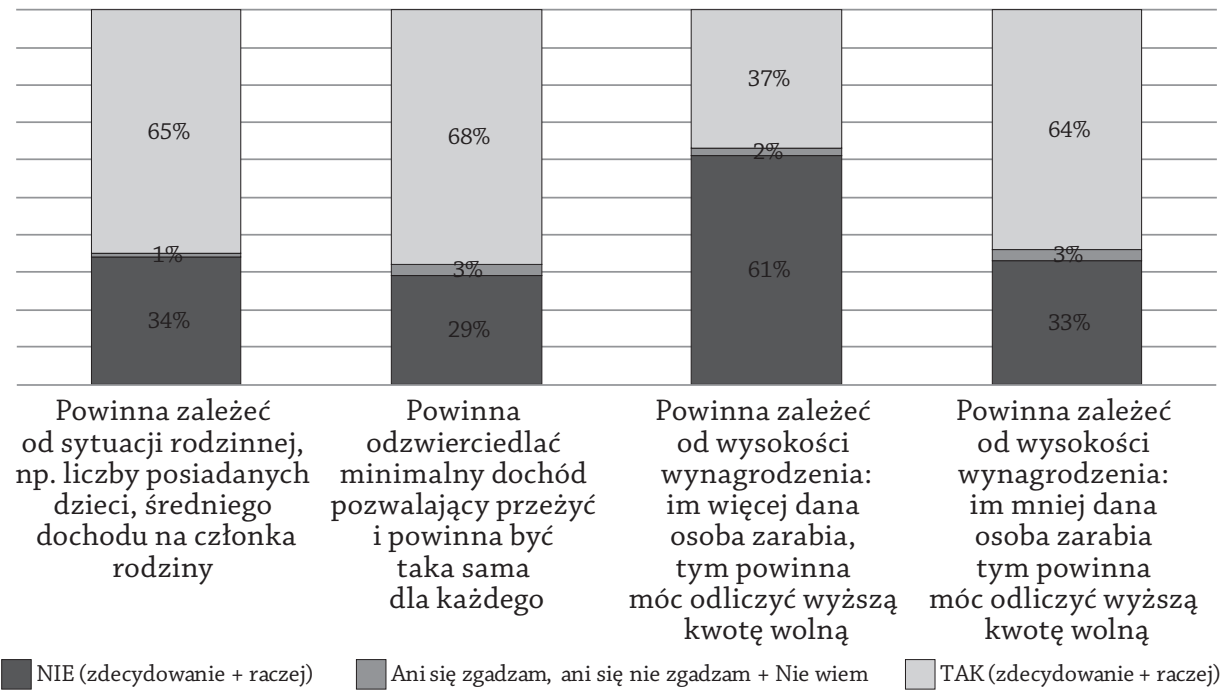

Uwaga: +\- różnice statystycznie w stosunku do wszystkich respondentów istotne na poziomie 95\%.

Źródło: badanie Kantar MillwardBrown.

badań w zakresie wniosków utylitarnych z przeprowadzonych badań de lege ferenda; aspekty te należałoby jednak ocenić także z punktu widzenia ekonomiki systemu podatkowego).

\section{Podsumowanie}

Minimum podatkowe jest rodzajem ulgi podatkowej, która odzwierciedla kwotę, poniżej której podatnik nie jest zobowiązany do uiszczenia podatku. Pełni zasadniczo dwie funkcje: odpowiada socjalnemu wymiarowi opodatkowania (na którą to funkcję został położony nacisk) oraz odnosi się do zasady taniości opodatkowania.

Jak wykazano, współczesne systemy podatkowe traktują koncepcję kwoty wolnej od opodatkowania jako czynnik socjalny. W swojej konstrukcji kwota wolna od opodatkowania powinna bowiem odpowiadać wartości koszyka dóbr i usług, który zapewnia społecznie akceptowalny minimalny poziom życia. Nieopodatkowanie tak określonego minimum egzystencji wymagałoby jednak indywidualizacji opodatkowania, a określone minimum odzwierciedlające społeczne minimum egzystencji powinno zależeć od sytuacji osobistej opodatkowanego. 
Próbą indywidualizacji kwoty minimum podatkowego i odwołania się do zdolności płatniczej podatnika była zmiana zasad jego ustalania w 2016 r. Do końca 2016 r. wysokość kwoty wolnej od opodatkowania była wartością stałą i wynosiła 556,02 PLN (Ustawa ..., 1991). Tak ukształtowany poziom kwoty wolnej w polskim systemie opodatkowania był jednak sprzeczny ze społecznym charakterem tej instytucji, nie odzwierciedlał bowiem różnicowania kwoty wolnej w odniesieniu do poziomu życia (rozumianego jako wysokość dochodu) podatnika. Z dniem 1 stycznia 2017 r. weszła w życie zmiana sposobu ustalania kwoty wolnej i jej częściowe uzależnienie od kwot dochodu osiąganych przez podatników. Ta indywidualizacja jest jednak częściowa, wskazuje bowiem arbitralnie ustaloną maksymalną wartość kwoty wolnej, która wydaje się być znacznie poniżej minimum egzystencji.

Zrealizowane badania opinii potwierdzają akceptację minimum podatkowego w deklarowanych postawach respondentów. Większość z nich wskazuje bowiem, że kwota wolna od opodatkowania powinna zależeć od wysokości wynagrodzenia oraz odpowiadać poziomowi minimalnego dochodu pozwalającemu przeżyć. Wnioski z badań mogą wskazywać na potrzebę dalszej indywidualizacji instrumentu kwoty wolnej od opodatkowania oraz relatywizacji do wysokości osiąganych dochodów. Na podstawie wyników przeprowadzonych badań widzimy jednak także relatywnie (do średniej z populacji) negatywny stosunek do instytucji minimum podatkowego reprezentowany przez grupę respondentów w najwyższej deklarowanej klasie dochodów. Podobnie jak w zakresie oceny instytucji progresywnego opodatkowania, negatywny stosunek może wynikać z odwołania się do kluczowych zasad, które odnoszą się do poczucia sprawiedliwości. W tym przypadku zasadą, będącą głównym czynnikiem branym pod uwagę przy ocenie sprawiedliwości wynagradzania, może być praca, której rezultat jest pochodną nakładu czasu pracy. Wówczas większego poświęcenia pracownika nie powinno się „karać” brakiem (lub mniejszym jej wymiarem) ulgi w postaci zwolnienia części dochodu z opodatkowania. Wyższe dochody mogą być związane w takim sposobie postrzegania zależności wzrostu zarobków z większym zaangażowaniem.

\section{Bibliografia}

Adam, L. (1962). Podatki i opłaty w kapitalizmie. Warszawa: PWN.

Douglas, R. (2011). The Lloyd George land taxes. Journal of Liberal History, 73, 4-13.

Etel, L. (2010). T. III: Prawo daninowe. W: System prawa finansowego. Warszawa: Oficyna a Wolters Kluwer business, 27-39.

Fedorowicz, Z. (1998). Historia podatków do końca IXI wieku - ze szczególnym uwzględnieniem Polski. W: Encyklopedia podatkowa. Warszawa: Wydawnictwo Naukowe PWN. 
Gomułowicz, A. (2001). Zasady podatkowe wczoraj i dziś. Warszawa: Dom Wydawniczy $\mathrm{ABC}$.

Jandy-Jendrośka, K. (1973). Progresja $w$ prawie podatkowym i jej zastosowanie przy opodatkowaniu dochodów w Polsce. Seria: Acta Universitatis Wratislaviensis. Prawo, nr 182. Wrocław: Wydawnictwa Uniwersytetu Wrocławskiego.

Kaplow, L. (2006). Taxation. Harvard Law School John M. Olin Center for Law, Economics, and Business Discussion Paper Series No. 542.

Konstytucja Rzeczypospolitej Polskiej z dnia 2 kwietnia 1997 r. Dz.U. Nr 78, poz. 483.

Kosek-Wojnar, M. (2012). Zasady podatkowe w teorii i praktyce. Warszawa: PWE.

Litwińczuk, H. (1989). Opodatkowanie rodziny. Warszawa: Wydawnictwa Uniwersytetu Warszawskiego.

Litwińczuk, H. (red.) (2012). T. II: Prawo podatkowe. W: Prawo finansowe. Warszawa: Oficyna Prawa Polskiego.

Morawiecki: Od 1 stycznia 2018 r. wyższa kwota wolna od podatku (2017). http://podatki. gazetaprawna.pl/artykuly/1072350,wyzsza-kwota-wolna-od-podatku-2018.html (1.07.2018).

Nie będzie wyższej kwoty wolnej od podatku. Sejm odrzucit projekt (2015). http://serwisy. gazetaprawna.pl/pit/artykuly/851989,nie-bedzie-wyzszej-kwoty-wolnej-od-pod atku-sejm-odrzucil-projekt.html (1.07.2018).

Nykiel, W. (2002). Ulgi i zwolnienia w konstrukcji prawnej podatku. Warszawa: Dom Wydawniczy ABC.

Obwieszczenie Marszałka Sejmu Rzeczpospolitej Polskiej z dnia 8 grudnia 2017 r. w sprawie ogłoszenia jednolitego tekstu ustawy o podatku dochodowym od osób fizycznych. Dz.U. z 2018 r. poz. 200.

Rybarski, R. (1935). Nauka skarbowości. Warszawa: F. Wyszyński i S-ka.

Smith, A. (1954). Badania nad natura i przyczynami bogactwa narodów, t. 2. Warszawa: PWN.

Sobiech, J. (2003). Kontrowersyjne problemy opodatkowania dochodów w Polsce. W: A. Pomorska (red.), Kierunki reformy polskiego systemu podatkowego. Lublin: Wydawnictwo UMCS, 195-201.

Sosnowski, M. (2015). Społeczny aspekt opodatkowania dochodów osób fizycznych w Polsce. Studia Ekonomiczne Uniwersytetu Ekonomicznego w Katowicach, 209, 188-197.

Topińska, I. (2017). Revision of personal income tax in Poland: Increase in tax-free allowance for the lowest earners. European Social Policy Network Flash Report, 2017/13.

Ustawa z dnia 26 lipca 1991 r. o podatku dochodowym od osób fizycznych. T.j. Dz.U. z 2012 r. poz. 361 z późn. zm.

Wyrok Trybunału Konstytucyjnego z dnia 28 października 2015 r., sygn. akt K 21/14. 


\section{Summary}

\section{Tax-free Amount vs. Tax Justice}

The paper discusses the problem of the tax-free amount constituting a tax minimum, below which the value of income earned is not taxable. The analysis has been made through the prism of the tax justice principles and the term of justice in terms of social policy. The Authors in the paper define the tax-free amount on the basis of literature review and determine its concept in a view of functions fulfilled by tax law. The results of research allowed to analyze how the respondents declare the assessment of the tax-free amount. Conclusions from the conducted studies may constitute a basis for further research on tax justice.

Keywords: remuneration, taxation, tax-free amount, minimum tax, minimum subsistence, income tax

\section{Dr hab. Aleksander Werner, prof. SGH}

Pracownik Katedry Prawa Administracyjnego i Finansowego Przedsiębiorstw Szkoły Głównej Handlowej w Warszawie, doktor habilitowany nauk prawnych, doktor nauk ekonomicznych, doradca podatkowy, radca prawny, były pracownik urzędu Komisji Papierów Wartościowych i Giełd. We zakresie nauk ekonomicznych obronił w SGH pracę doktorską pt. Pomoc publiczna dla przedsiębiorców a ochrona konkurencji. Przewód habilitacyjny przeprowadzony na Wydziale Prawa Uniwersytetu w Białymstoku dotyczył prawa podatkowego (monografia habilitacyjna pt. Adekwatność sytuacji prawnopodatkowej polskich przedsiębiorców dla ich roli $w$ gospodarce. 2013. Warszawa: SGH). Od kilku lat prowadzi wykłady m.in. z prawa podatkowego, prawa ochrony konkurencji, prawa rynku kapitałowego oraz prawa gospodarczego. Jest autorem wielu publikacji z zakresu swojej specjalizacji. Od ponad 10 lat wykonuje zawód radcy prawnego.

\section{Dr hab. Jacek Wasilewski}

Doktor habilitowany nauk politycznych. Pracę doktorską pt. Retoryka dominacji obronił w 2004 r. na Wydziale Dziennikarstwa i Nauk Politycznych UW. Habilitację uzyskał w 2014 r. na podstawie pracy pt. Opowieści o Polsce. Retoryka narracji. Od roku 2011 kieruje specjalnością Dokumentalistyka, której celem jest rozwijanie multimedialnych dziennikarskich form narracyjnych. Członek Komisji Żywego Słowa Rady Języka Polskiego. Zajmuje się ekspertyzami dla sądów, KRRiTV, stacji 
medialnych i innych podmiotów publicznych. Współpracował z Krajową Szkołą Sędziów i Prokuratorów, prowadził zajęcia z retoryki w Okręgowej Izbie Radców Prawnych w Warszawie.

\section{Mgr Katarzyna Kimla}

Studentka III roku studiów doktoranckich w Szkole Głównej Handlowej w Warszawie. Współpracuje z Katedrą Prawa Administracyjnego i Finansowego Przedsiębiorstw SGH. Jej zainteresowania naukowe skupiają się przede wszystkim na zagadnieniach prawa podatkowego, ekonomicznej analizy prawa regulacji podatkowych oraz wpływie podatków na funkcjonowanie przedsiębiorstw w gospodarce. Dysertacja doktorska dotyczy problemu przerzucalności ekonomicznego ciężaru opodatkowania na podmioty trzecie w perspektywie indywidualnych rozstrzygnięć organów podatkowych i sądów administracyjnych.

\section{Mgr Agata Kostrzewa}

Studentka I roku studiów doktoranckich na Wydziale Dziennikarstwa Informacji i Bibliologii Uniwersytetu Warszawskiego. Jej zainteresowania naukowe skupiają się na analizie dyskursu medialnego, ze szczególnym uwzględnieniem narracji i argumentacji dotyczącej polityki społecznej, zwłaszcza w zakresie edukacji, polityki rodzinnej, polityki rynku pracy oraz nierówności społecznych, równouprawnienia i dyskryminacji. 